The role of street-level bureaucracy in the implementation and (re)formulation of the health service's Humanization Policy in Porto Alegre (RS)

Luciana Leite Lima

Universidade Federal do Rio Grande do Sul / Programa de Pós-Graduação em Políticas Públicas

Porto Alegre / RS - Brazil

Luciano D'Ascenzi

Governo do Estado do Rio Grande do Sul / Agência Estadual de Regulação dos Serviços Públicos Delegados do RS

Porto Alegre / RS - Brazil

\begin{abstract}
This article analyzes the implementation of the National Humanization Policy in basic health units of Porto Alegre. For this, we analyzed interaction that emphasizes the process of mutual influence between the planning of public policy and characteristics of local implementation. Thus, this perspective is from the context of operations of street-level bureaucracies, emphasizing the role played by its discretion. The study was qualitative with the use of primary and secondary data. We examined implementers, given the lack of training in the policy framework, as well as perceptions on the lack of resources and low levels of support, which forged a peculiar understanding of the goals and strategies of public policy. They created a vision of what it would mean to humanize the service when adjusted to local preferences and needs.
\end{abstract}

Keywords: public policy; implementation; street-level bureaucracy.

\title{
0 papel da burocracia de nível de rua na implementação e (re)formulação da Política Nacional de Humanização dos serviços de saúde de Porto Alegre (RS)
}

Este artigo analisa a implementação da Política Nacional de Humanização nas unidades básicas de saúde de Porto Alegre. Para isso, foi utilizada a abordagem de análise baseada na interação que enfatiza o processo de influência mútua entre o plano da política pública e as características dos espaços locais de implementação. Assim, situa o olhar nos contextos de atuação das burocracias de nível de rua, ressaltando o papel exercido por sua discricionariedade. A pesquisa foi qualitativa com a utilização de dados primários e secundários. Averiguou-se que os implementadores, diante da falta de treinamento nos marcos da política, da percepção de carência de recursos e do baixo grau de apoio, forjaram um entendimento peculiar dos objetivos e das estratégias da política. Eles criaram uma visão do que seria humanizar os serviços, inspirada pela estrutura normativa e ajustada às preferências e necessidades locais.

Palavras-chave: políticas públicas; implementação; burocracia de nível de rua.

\section{El papel de la burocracia de nivel de calle en la implementación y (re)formulación de la Política Nacional de Humanización de los servicios de salud de Porto Alegre (RS)}

Este artículo analiza la implementación de la Política Nacional de Humanización en las unidades básicas de salud de Porto Alegre. Para ello, se utilizó el método de análisis basado en la interacción que hace hincapié en el proceso de influencia mutua entre el plan de las políticas públicas y las características de los espacios locales de implementación. Por lo tanto, la mirada se encuentra en el contexto de la operación de las burocracias del nivel de la calle, haciendo hincapié en el papel desempeñado por su discreción. El estudio fue de tipo cualitativo con el uso de datos primarios y secundarios. Se averiguó que los implementados, delante de la falta de entrenamiento en los marcos de la política, de la percepción de carencia de recursos y del bajo grado de apoyo, forjaron un entendimiento peculiar de los objetivos y de las estrategias de la política pública. Ellos crearon una visión que sería humanizar los servicios, ajustada a las preferencias y necesidades locales. La política implementada difirió de la política formal. Con todo fue esa adaptación que permitió la implementación de hecho.

Palabras clave: políticas públicas; implementación; burocracia de nivel de calle. 


\section{INTRODUCTION}

The purpose of this article is to analyze the implementation of the National Humanization Policy in the Basic Health Units in the city of Porto Alegre, Brazil ${ }^{1}$. This research addresses the process of (re) design of the policy during its implementation. Our argument is that this process results from a mutual influence between the policy's formal normative structure and the contexts within the implementation.

The perspective presented in this article values the context in which the policy is implemented and the focus of analysis are the street-level bureaucracies. We will be attentive to the discretion of these actors, emphasizing their practice and informal organizational routines that constitute the policy on the ground (Brodkin, 2011; Lipsky, 2010). The article investigates how the decisions and actions of the actors responsible for the policy implementation contribute to its (re)design and how this process is influenced by the normative structure. Aligned with authors such as Gofen (2014), Oliveira (2012), Brodkin (2011), Tummers (2011), Lotta (2012b) and Pires (2009), we assume that decisions and actions of the 'frontline' actors change the policies paths, influencing their results.

Besides this introduction, this article is structured into five additional sections and concluding remarks. Next, we discuss the theoretical and analytical framework, followed by research methods. The fourth section shows how policymakers describe the humanization policy. The fifth section presents and analyzes the data collected. The sixth part outlines the humanization policy produced from the interaction between normative structure and local contexts of action. Finally, we present our concluding remarks.

\section{THEORETICAL AND ANALYTICAL FRAMEWORK}

The policy cycle is an analytical tool that enables to breakdown policies in agenda setting, policy formulation, decision-making, policy implementation and policy evaluation (Howlett et al., 2013). ${ }^{2}$ This article focuses on the implementation step, i.e., the execution of the decisions $s^{3}$ made during the policy cycle.

The study of public policies considering the steps above has led to the development of specific analytical models. For those regarding implementation, a basic issue is the relationship between what was planned and the actual operation. Based on this somewhat interdependent relationship, models can be classified into three broad approaches: control, interaction and cognition (Lima and D’Ascenzi, 2014).

Control-based approaches consider implementation as a consequence of planning which would be a prescriptive element. Perspectives based on interaction focus on the implementation context: besides the plan itself, they consider organizational resources, the operators, their values and behaviors. Cognitive approaches, however, emphasize ideas and action that shape implementation. The analysis here is aligned with interaction approaches. ${ }^{4}$

\footnotetext{
${ }^{1}$ This article is one of the products of the research "Public Policy Implementation and Community Participation", funded by the Rio Grande do Sul Research Support Foundation (FAPERGS).

${ }^{2}$ Variations of these steps can be found in Muller and Surel (2002), Hill and Hupe (2014) and Secchi (2015).

${ }^{3}$ About the limits of the sequential approach, see Muller and Surel (2002) and Zani and Costa (2014). About the interdependence between steps, see Browne and Wildaysky (1984) and Pinto and Midlej (2012). About the Brazilian production, see the systematization provided by Lotta (2012a) and Marques (2013).

${ }^{4}$ These categories are presented and discussed in Lima and D’Ascenzi (2014).
} 
Interaction approaches consider the relation between the steps of the policy cycle, considering implementation as a result of an interaction process between the formal normative structure and the characteristics of the operation spaces (Lima and D'Ascenzi, 2013). On one hand, the plan defines: the arena in which the process occurs, the role of the actors, the tools, the allocation of resources. It also provides a definition for the social problem, influencing the operators' performance (Hupe, 2014; May, 2012; Hupe et al., 2014; Majone and Wildavsky, 1984). On the other hand, the implementation promotes the adaptation of goals and management tools to social reality.

According to Majone and Wildavsky (1984), the plan exists as potential; its implementation depends on intrinsic qualities and external circumstances. From this point of view, the policy would be a set of dispositions working as a starting point for an experimental process. Due to the bounded rationality, it would not be possible to predict social problem behaviors, nor the policy dynamics. That is, social issues would only be acknowledged from the attempts to solve them. Both the capacity and effectiveness of the tactics chosen to face the issues would only be confirmed after they came into operation. In this case, implementation includes seeking answers and (re)asking questions, leading to changes in solutions and in the way social issues are understood. This results in a continuous process of adapting the plan to the context, which would be the essence of implementation. Adaptation is an intrinsic feature, occurring at the expense of rigid control mechanisms (Lima and D'Ascenzi, 2014).

Such dynamics are made possible and undertaken through discretion. An issue that can be approached from the work of Lipsky (2010) on street-level bureaucracies, agencies in which public service workers interact directly with citizens in the course of their tasks, having substantial discretion in the operation of the service. The author argues that the decisions of these bureaucrats, the routines they establish and the mechanisms they create to deal with the uncertainties and work, certainly become the public policies.

Based on Lipsky (2010), discretion would be a consequence of a few elements. First, discretion would derive from professional knowledge, it is expected that professionals judge and decide when it comes to issues related to their field, i.e., they must exercise discretion. Second, street-level bureaucracies are often permeated by multiple rules that constantly change. This encourages selective use and makes supervision difficult. Lipsky points out that street-level bureaucrats operate in highly regulated environments that, paradoxically, encourage discretion and constrain hierarchical control. Third, the relative autonomy of organizational authority, related to the two previous elements. As shown, the multiplicity of rules makes supervision difficult, and professional knowledge, exercised in a context of direct interaction with citizens, produces a dilemma of information asymmetry: the manager has limited access to information about the operator's practices.

Working conditions play a central role in the exercise of discretion. They are the conditions that enables discretion, determining the operators' performance. A feature of these conditions is the chronic insufficiency of resources to carry out the expected activities, which leads to making decisions on the allocation of scarce resources. In addition, the demand for services tends to increase until the supply is found; for Lipsky, this would imprison these bureaucrats in a cycle of mediocrity: the better the service, the greater the demand. Another aspect concerns the policy goals, which are often vague, conflicting and ambiguous, making it hard to establish tasks. On this matter, Wilson (2000) asks and replies: if the goals are not clear, how are the tasks established? By work circumstances, previous experiences, professional norms and bureaucratic personality. It is difficult, however, to measure the performance of these workers because of the relative autonomy of organizational authority and because 
of the discretion. Lastly, the non-voluntary feature of clients, who are not in the position to discipline the bureaucrats that, in turn, have little to lose by failing them. According to Lipsky (2010:55) if the demand for services is practically inexhaustible in relation to supply, the fact that some clients are dissatisfied with the quality or level of services means that others who are willing to accept such costs will take their places. In this context of considerable uncertainty, bureaucrats make decisions, which effectively shape public policy.

Therefore, the use of discretion by street-level bureaucrats is related to the characteristics of the operation spaces. It does not only reflect individual preferences, but is shaped by organizational routines, tools and norms (Soss et al., 2011; Brodkin, 2011). Brodkin (2007) draws attention to two facets of discretion. On one hand, it is necessary: services require responses to complex and specific circumstances, as well as judgments. On the other hand, it makes it possible for frontline actors to control the delivery of the service, creating a variety of practices.

Thus, there is no question as to whether there is discretion in street-level bureaucracy, but how does this happen, and what are the consequences for public policies regarding operation, results and final design (Gofen, 2014; Tummers, 2011; Bastien, 2009).

\section{RESEARCH METHODS}

In this research, the analysis is aligned with the perspectives that emphasize the interaction between the normative structure of the policy and the features of the implementation contexts. It is important to clarify two assumptions: the values expressed by the policy influence the behavior of those who are implementing it; and the adjustments made by those implementing the policy change its goals, tactics and products. The result of this dynamic is a hybrid public policy, which is experienced by the citizen and represents the bases on which the citizen evaluates the relationship between the State and society.

Based on the literature presented, three groups of variables were established:

a) knowledge and understanding of the policy by the operators: refers to the degree operators are familiar with the policy plan, aiming at investigating the ways in which the plan influences the operators' behavior;

b) organizational conditions: refers to the perception of the actors and how it affects their practices;

c) operators compliance with the principles and goals: refers to the degree of conflict/acceptance of the policy goals and strategies, and how they are expressed in practice.

The empirical work consisted in the analysis of the implementation of the National Humanization Policy (NHP) in the basic health units (BHUs) of the city of Porto Alegre, Brazil. The NHP was chosen because: a) the analytical approach requires the study of initiatives that are operationalized through street-level bureaucracies (more common in social policies); b) the approach calls for an initiative in the implementation phase, which was the case of NHP at the time the research was designed. The choice for the city of Porto Alegre was due to the size of the service's network and of its population, as well as the city's historical record in focusing on the primary care network (Lima, 2012).

The Ministry of Health (MH) at the federal government formulated the NHP. Its operationalization, however, depends on the municipalities. Although municipalities have autonomy to manage the health system in their territory, they find it difficult to develop the capacity to formulate and finance such policies. Against this backdrop, in the 1990s, the MH started acting as a formulator and financier, 
inducing the participation of States and cities. It is in this context that the National Humanization Policy was formulated.

The research loci were the basic health units, which are part of the structure of operation of the health system and are responsible - alongside the family health units - for the population's primary care, performing first care and referring to other services. In 2013, Porto Alegre had 45 BHUs distributed in eight 'health regions'. Each region has a district health management, which manages the entire health care network in its territory.

The NHP was presented by the Ministry of Health in 2003 and the Secretary of Health of the city of Porto Alegre (SH) formally joined in 2004. In 2006 the city established the Humanization Committee, with the purpose of disseminating and encouraging the implementation of the policy. Since then, activities related to the policy should be included in the health unit's management reports. These reports are accountability tools and support the elaboration of the Secretary of Health's management reports, which are evaluated by the Municipal Health Council and used to publicize the activities related to health care in the city.

For this research, primary and secondary data were collected. The primary data were gathered from semi-structured interviews about the policy implementation with 42 BHUs coordinators, conducted between 2013 and 2014. These actors are considered street-level bureaucrats because they fulfill the main characteristic defined by Lipsky (2010): they interact directly with the citizens in the development of their activities.

The set of secondary data was composed of the communication materials produced by the Ministry of Health, in which it details the policy, exposing the intentions of the policy-makers. The data were treated with NVivo software and analyzed through content analysis, organized according to explanatory variables.

\section{NATIONAL HUMANIZATION POLICY ACCORDING TO THE MINISTRY OF HEALTH}

According to the Ministry of Health, the Humanization Policy deals with the problems of "fragmentation and verticalization of work processes, which jeopardize the relationships between the different health professionals and between health professionals and users" (Brazil, 2004a:5), as well as dealing with the "unpreparedness of professionals to work with the subjective dimension" of health practices (Brazil, 2004b:8).

Humanization is understood as "the appreciation of the different subjects involved in the process of health production: users, workers and managers" (Brazil, 2004b:8). This is to "increase the degree of co-responsibility of the different actors that constitute the national health system's network in the production of health"; this would require "a change in the culture of care towards users and management of work processes" (Brazil, 2004a:7).

The policy has a precise focus: "to invest in the production of a new type of interaction between the subjects involved in the health systems and use them, welcoming these actors and promoting their protagonism" (Brazil, 2004a:8). "The values that guide this policy are the autonomy and protagonism of the subjects, the co-responsibility between them, the establishment of solidarity bonds and the collective participation in the management process"(Brazil, 2004b:9).

This would be operated through the following structure (Brazil, 2008): 
a) Principles: transversality, indissociability between attention and management, protagonism, corresponsibility and autonomy of the subjects and collectives.

b) Method: inclusion of the different actors in decision making processes.

c) Guidelines: expanded clinic, co-management, reception, appreciation of the work and worker, protection of the users' rights, promotion of groups, building the Memória do SUS que dá certo (memoir of the national health system that works)

d) Instruments: Humanization Working Group, Technical Committee on Humanization, management group, management contract, systems to obtain qualified feedback from users and workers in healthcare, open visits and the right to be accompanied by a family member or friend, workers training in healthcare, expanded research community, transdisciplinary reference team and support from specialists connected to reference teams, ambience co-managed projects, reception with risk classification, singular therapeutic project, project for collective health and the project Memória do SUS que dá certo.

For basic attention, the NHP believes that it is possibility to build a "community zone", a "common ground" between the different interests of managers, workers and users (Teixeira, 2005 apud Brazil, 2009). This tactic should be operated through building collective spaces.

\section{IMPLEMENTATION OF THE HUMANIZATION POLICY IN BASIC HEALTH UNITS}

To describe the implementation of NHP in the health units, two aspects were emphasized: the participation in the Humanization Working Group (HWG) and implementation of the activities of the NHP.

The HWGs are one of the main tools in the implementation of the NHP. They are established at the district management level and aim to disseminate and encourage the policy's implementation. Coordinators, or other public service workers coordinators designate, participate in the groups. Although the HWGs were already instituted in the eight districts, in each district, there was at least one coordinator who did not know about the working group.

\section{TABLE 1 IMPLEMENTATION OF HWGS}

\begin{tabular}{l|r|r|c|c|} 
& Yes & No & Unknown & Total \\
\hline There is HWG in the district management & 25 & 10 & 7 & 42 \\
\hline The coordinator of the BHU participates & 6 & 19 & - & 25 \\
BHU sends a representative person & 12 & 6 & 1 & 19
\end{tabular}

Source: Elaborated by the authors.

In the 42 BHUs studied, 18 had sent representatives to the HWGs, of which 12 were public service workers designated by coordinators. The designated workers were chosen based on different criteria: district management decision; affinity with the widespread idea of humanization (that is, professionals viewed as kind and therefore more likely to humanize); lack of affinity with the widespread idea of humanization (that is, professionals seen as intractable and thus more likely to be humanized); and 
the availability and motivation of the worker. These elements are clues about how the bureaucrats view humanization: humanizing is to treat people well.

It is worth investigating in these 18 cases where there is participation in HWGs, whether there is effectiveness in achieving the groups' goals of disseminating and encouraging the NHP. To this end, participants should take the issues addressed in the HWG to their unit team meetings. As table 2 shows, no respondent was able to explain or specify the issues discussed in the working groups. All the subjects where mentioned in a generic way, without any mention of the NHP.

\section{TABLE 2 SUBJECTS DISCUSSED BY THE HWG}

\begin{tabular}{lc} 
& Number of respondents \\
\hline Debate about humanization and reception & 10 \\
Debate about problems at the BHU & 2 \\
Meetings & 1 \\
Unknown & 5 \\
\hline
\end{tabular}

Source: Elaborated by the authors.

On the implementation of the HWG, it is possible to draw two conclusions. First, the existence of the groups and the debates held in them were not disseminated. Second, although 18 units sent representatives to the meetings, no respondent showed they knew the issues discussed. Against this backdrop, it is surprising that only one respondent reported not performing any humanization action; the others stated that the BHU in which they worked implemented at least one activity for humanization. If the HWGs were the instruments of diffusion of the policy and its operation was deficient, what would explain the propagation of the NHP? To answer this question, one must pay attention to the object of the implementation: what has actually been carried out?

The most widespread activity was the reception, mentioned by 27 respondents. However, two observations must be made. This activity had the first implementation attempt in 2001, and, according to the interviewees, it was unsuccessful. The Ministry of Health presents the reception as one of the main guidelines of the NHP in 2008 and this was the best-known action. The second observation is that actors attributed different meanings to 'reception', among them: serving the user the moment they arrive in the unit; to refer the user if it is not possible to solve their problem in the unit; to listen to the user; schedule medical appointments, providing access to services; to approach users outside the unit in order to attribute responsibility for non-attendance at scheduled appointments and other services; do not leave the user unattended; do not control access to medical appointments by distributing numbers to be picked up upfront; guide and advise users on medication use, test results and referrals to other services; provide good service, be resolute; provide good reception, be polite, treat users with affection, know how to deal with conflicts; host users when they arrive at the unit; have a room to listen to the user's demand. 
In addition to the reception, chart 1 shows 23 different activities mentioned by the interviewees as part of the Humanization Policy.

\section{CHART 1 ACTIVITIES OF THE NHP}

1. Appointment scheduling.

2. Ambience (decoration of the unit for campaigns, renovation of walls and waiting rooms).

3. Assistance regarding women's rights.

4. Good service.

5. Prenatal care.

6. Health promotion activities.

7. Activities in schools (informative speech, visit, vaccination).

8. Active search (technical procedure of action in epidemiological surveillance).

9. Raise awareness among users about the waste of resources caused by missing appointments.

10. Talking to workers.

11. Elaboration of training courses.

12. Efforts to maintain appointments in face of lack of resources.

13. Forming the Local Health Council (a committee formed by users and unit personnel in order to promote social accountability).

14. Offering appointments with a Psychiatrist.

15. Celebrations among workers (Birthdays, Christmas, New Year).

16. Participation in training courses.

17. Form information and prevention groups (pregnant women, people with diabetes, asthma, drug addicts).

18. Provide itinerant tests (STD, HIV, pregnancy, diabetes).

19. Solving problems that are not part of the routine of the unit.

20. Team meetings.

21. Waiting room (activity using the space of the waiting room to provide health information).

22. Everything that is performed in the reception.

23. Home visiting.

Source: Elaborated by the authors.

Some of these activities were part of the BHUs routine before the NHP, for example: team meetings, information and prevention groups, participation in training, home visit. Others can hardly be considered as "activities": 'everything that is performed in the reception', 'talking to workers'. The diversity of activities cited is an important fact, as it is the indication of routine or vague tasks. 
In addition, initiatives such as activities in schools, active search and assistance regarding women's rights are responses to the characteristics of the territory. The active search situations reported, for instance, were voluntary initiatives of professionals who, using their own vehicles or public transportation (spending their own money), visited people with mobility problems or contagious diseases that, for some reason, did not attend the scheduled appointment. The women's rights assistance was an initiative of a nurse, she was aware of administrative procedures directed at women in situations of risk or violence.

None of this was foreseen by the $\mathrm{SH}$, nor was it clearly listed in the tasks to be developed at the BHUs and none were part of the NHP. These activities were elaborated and implemented to meet local needs and were always referred to as the result of an individual and personal effort by public service workers in order to meet the users' needs. Thus, if on one hand the product of voluntarism is the apparent lack of standards in implementation, on the other hand it is the appropriation and control of the work and the priorities, which are specific to each place, by the implementing bureaucracy.

Regarding the typical actions of the NHP, 06 respondents mentioned the team meetings, and only one mentioned the Local Health Council. Again, it is important to observe the fact that these activities were in place before the implementation of the policy.

It was possible to observe that the actors developed quite distinct ideas about the activities that would form the NHP, triggering a process of policy reformulation. The following section shows data referring to the explanatory variables.

\subsection{POLICY KNOWLEDGE AND UNDERSTANDING}

The variable policy knowledge and understanding was obtained using the following sub-variables: policy knowledge, access and sources of informative material, training and understanding of the goals.

All interviewees' responded they knew the NHP. Answers ranging from "have an idea" to "know the goals and guidelines" were considered as "knowing the policy". As for the sources of information about the policy, the responses varied as presented in table 3.

\section{TABLE 3 SOURCES OF INFORMATION ABOUT NHP}

$\begin{array}{lc} & \text { Number of respondents } \\ \text { Meetings with the district managers } & 16 \\ \text { Training courses offered by the SH } & 9 \\ \text { Graduation courses or specialization } & 5 \\ \text { Meetings with the HWG } & 2 \\ \text { Do not remember } & 2 \\ \text { Other (teaching, preparing for an application for public service, training in previous job, own } & 8 \\ \text { research) } & 2\end{array}$

Source: Elaborated by the authors. 
Only two coordinators learned about the policy through the HWGs. The coordinators did not know the guidelines and the goals of the policy, with the exception of those that studied the policy at university (graduation, specialization or teaching). The coordinators that learned about the policy through training courses offered by the city's Secretary of Health, reported to have studied the policy in a transversal way. The subject was addressed through activities about medical care.

\section{TABLE 4 ACCESS TO INFORMATIVE MATERIAL AND TRAINING ABOUT THE NHP}

\begin{tabular}{|lccc} 
& Yes & No & Do not remember \\
\hline Received informative material & 16 & 22 & 4 \\
\hline Received training & 12 & 30 & - \\
\hline
\end{tabular}

Source: Elaborated by the authors.

As for the access to informative material, the research took into consideration everything that contained information about the principles, goals and strategies regarding the policy. Sources could be books received during training courses (even though they had been lost), pamphlets, e-mails received from the district management, printed material received in previous jobs, printed slides, copies of texts, voluntary online research. None of the coordinators reported to have received material produced by the Ministry of Health.

Regarding training, the research considered anything from training courses to informative speeches. Table 5 shows that only one coordinator was trained about the NHP.

\section{TABLE $5 \quad$ LOCATION OF TRAINING AND SUBJECTS COVERED}

\begin{tabular}{l|c|c|c} 
Location of training & $\begin{array}{c}\text { Number of } \\
\text { respondents }\end{array}$ & Subject covered on training from the SH & $\begin{array}{c}\text { Number of } \\
\text { respondents }\end{array}$ \\
\hline Previous employer & 1 & SUS - Brazilian National Health System (general characteristics) & 7 \\
\hline $\begin{array}{l}\text { City Secretary of Health } \\
\text { (SH) }\end{array}$ & 11 & Reception & 3 \\
\hline
\end{tabular}

Source: Elaborated by the authors.

As of 2006, SH started to require the inclusion of humanization activities in the management reports of the BHUs. Thus, the coordinators were led to implement humanization actions, although they had little or no access to the content of the policy. This context of institutional incentive for the implementation alongside the scarcity of institutional resources to do so, favored the phenomenon of appropriation and reformulation of the policy. 
The process of re-signification can be observed through the actors' views in relation to the policy goals. There were 29 different goals that were grouped into four dimensions.

\section{CHART 2 NHP GOALS}

\begin{tabular}{|c|c|c|}
\hline Goals & Mentions & Other Information \\
\hline \multicolumn{3}{|c|}{$\begin{array}{l}\text { Focus on care and services } \\
\text { Goals mentioned: } 14\end{array}$} \\
\hline Reception & 20 & Referred to as objective and also as implementation strategy \\
\hline Good service & 13 & $\begin{array}{l}\text { - } \\
\text { - Take into consideration more than only biological aspects. } \\
\text { - Provide resolution. } \\
\text { - Respect patients. } \\
\text { - Provide a more personalized human and affective service. } \\
\text { - Serve with equality. }\end{array}$ \\
\hline Others & 32 & $\begin{array}{l}\text { - Feel responsible for the users. } \\
\text { - Improve users' quality of life. } \\
\text { - Provide inter-sectorial services. } \\
\text { - Promote groups of preventive activities and quick tests. } \\
\text { - Guarantee that users and workers are happy. } \\
\text { - Improve access. } \\
\text { - Guarantee universal access, despite beliefs. }\end{array}$ \\
\hline
\end{tabular}

\section{Focus on the relationship with user}

\section{Goals mentioned: 4}

\section{Users education}

Facilitate the relationship between user and worker

Others

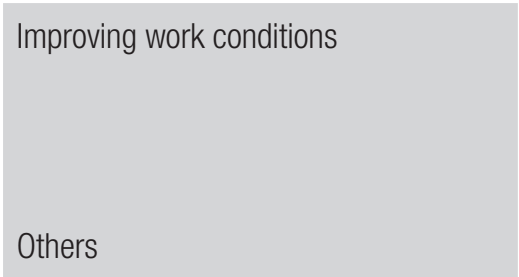

Users must know the health system problems and how it works, as well as being responsible for their own health.

2

2

- Guarantee users rights.

- To have good relationship with the community.

\section{Focus on the workers}

\section{Goals mentioned: 5}

6

- Permanent training.

5

- Workers' health.

- Reception of the worker.

- Workers' humanization. 


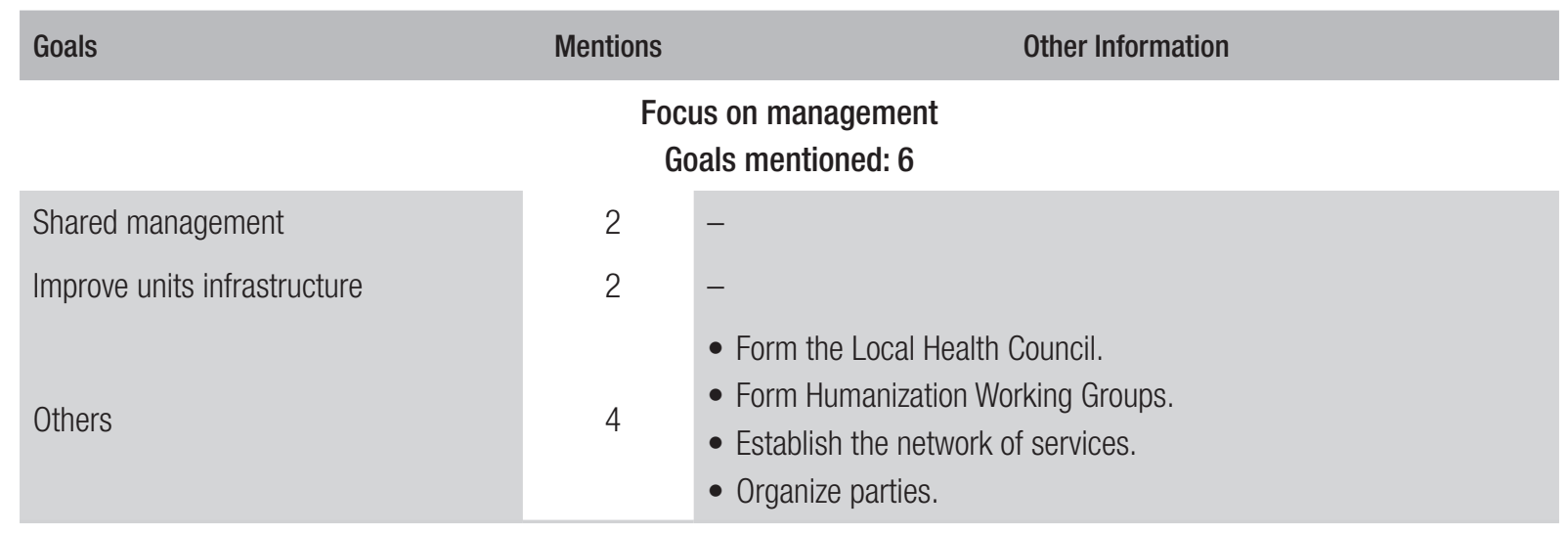

Source: Elaborated by the authors.

The actors did not share the same understanding about the policy's goals. Among the several responses, it is possible to note the free and subjective interpretation of the policy, from what its name suggests. Humanizing, in the perception of the actors, was related to affection, happiness, kindness, respect, personalization.

Finally, it was observed that the process of socialization in the policy plan was little elaborated and the operators of the policy were called upon to perform the tasks without clear guidelines. This resulted in several different interpretations about the goals guiding the definition of what should be done: it is possible to identify the connection of the activities attributed to the NHP (chart 1) to the goals (chart 2). Moreover, the term "humanization" strongly influenced the delimitation of the goals. Here the interaction between the plan and the organizational context is detected: in an environment of limited information and organizational determination, an element offered by the plan served as the basis for (re)formulation. In this sense, the result of the implementation is highly adjusted to the local reality. The derived policy expresses the dynamic interaction between the context, the formal public policy and the perceptions of the operators.

\subsection{ORGANIZATIONAL CONDITIONS}

Regarding the variable organizational conditions, the perception about the quantity and quality of human resources and the infrastructure of the BHU was considered.

As for human resources, there was a widespread impression of lack of personnel to develop the actions that the $\mathrm{SH}$ and the community expected $\mathrm{BHU}$ to carry out. The majority of the interviewees (36) pointed out the lack of personnel and the increased workload due to the implementation of the policy. The concern with the administrative services was recurrent, as there is no provision of professionals for this area in the staff of the BHUs. Administrative services were performed by health professionals and, in some cases, with the assistance of security guards. According to an interviewee: "So who answers the phone? By camaraderie, the security guard".

Cleaning and security workers are outsourced and their participation in administrative activities was voluntary, so the situation varies among BHUs. In addition, interviewees pointed out that the operation of administrative activities by health professionals deviates them from their original role as health services providers, which increases the perception of lack of personnel. Administrative work was considered unproductive, and its operation generated tension with the health system management body. The following statements illustrate the situation: 
This kind of repetitive demand is tiring. It is bureaucratic; at the end, it does not change anything. [The city Secretary of Health asks for] the number of prescriptions released in a $\mathrm{BHU}$, which is useless because one prescription may request 30 different drugs, or only one. I will have to allocate an employee to provide this information. Already an employee controls the stock of medicines. Do I need to have the number of prescriptions? No. However, they $[\mathrm{SH}]$ demand this information from me every month. What for? It does not add any value, it is not going to change the routine of the unit and it is not going to bring an assistant to the units' pharmacy.

We do not have an employee for administrative activities. Our health professionals do this kind of service, reception, medicine distribution and other things they should not be doing, right? But here, because everybody helps, things work properly, even though it is not the right way.

The strong perception of a lack of human resources makes voluntarism a central element. Individual effort appears as an important resource used by the organization in order to achieve its goals in a context of scarcity. The appreciation of individual effort, which was often considered the reason the activities could be performed and maintained, minimizes the feeling of impotence and can even overshadow the lack of resources.

This situation is illustrated by the following statements: "[...] of course there is always a shortage of human resources, I think you will hear that everywhere! But I think that with the effort of the people, you can do it."

A person who comes for this test (HIV) will take, at least, 20 minutes. After that, I will have to come back to bring the results. And I will pray for the result to be negative, but of course some positive results show up some times. And then, when the person sees a positive result, showing they have got HIV [I have to say]: excuse me I have the next [user to attend] now... This part I think we are failing... in this issue... if we are talking about humanization, I think there is a lack of resources in this sense. If you ask me: is everything working properly? It works because we put a lot of effort into it.

I think our group excels in this care. Because they live around here, the majority of the professionals, the ones working for a long time, they were raised here, so they know the people. There are connections such as a godfather, godmother, cousin, a distant uncle, neighbor's friend [...]. So people feel committed to each other.

The quality of human resources was accessed through the perception on the offer of training courses. Eighteen respondents stated that there is an adequate supply, 14 consider that there is a lack of training and 10 believe that training is an irrelevant issue in the face of a shortage of personnel. The training courses mentioned were focused on technical and service related procedures, and no respondents mentioned courses for unit management. The organization of the unit's routine was staff's and coordination's responsibility. This routine is formed by both technical and service related, as well as administrative activities. Considering that public service workers were not trained to 
perform administrative activities, what is observed, in the words of a respondent, is the feeling that "[we] spend the day putting out fires". This situation may result in a strong perception of shortage of human resources, because the access and service flows are defined based on variety of criteria and on the day-to-day experience.

Regarding the infrastructure of the units, 30 coordinators considered it inadequate. This evaluation was based on the lack of space to serve users, conduct administrative activities and to attend to the needs of the workers (kitchen, resting areas, changing room and bathroom).

Therefore, the research identified a strong perception that the resources available for the operation of the activities were insufficient, and this has made room for the appreciation of an individual resource: voluntarism. The voluntarism filled the gap left by lack of human resources, training, and adequate infrastructure. Individual characteristics would explain the maintenance of services in such a context. For the implementation of the policy, this implies the mobilization of individual values in the organizational decisions, the generation of a great variety of behaviors and the production, from the managerial point of view, of low governability. All these elements were consubstantiated in redefining the policy's goals and activities locally, as previously shown.

\subsection{OPERATORS COMPLIANCE WITH POLICY'S PRINCIPLES AND GOALS}

The variable operators' compliance with the principles and goals was obtained through the point of view of the interviewees.

The most widespread point of view was that the NHP would not be adequate to the reality of constraints and limitations that prevailed in the units. For the interviewees, the implementation would imply an overload of work for professionals who are already experiencing an extremely troubled routine. They emphasized that the increase in the demand for services required for the several programs that must be carried out, was not accompanied by appropriate resources.

As pointed out above, there was a highly widespread perception of inadequacy and lack of working conditions that actors brought up when reflecting on their performance in the implementation of the policy. Evidence of this is the fact that all the coordinators mentioned the lack of resources when elaborating their answers about the NHP principles and goals.

In addition, there was a certain disconcert about the idea of a policy that proposes to humanize a service rendered by people to people. As well as challenging a humanist identity, the problems of the functioning of services would be due to the behavior of the workers, not to the lack of resources. According to a coordinator: "what I am afraid of, I will be honest, [...] is that this may be used by management [of the $\mathrm{SH}$ ] to consider everything [all health service problems] the responsibility of the professional".

Thus, only nine coordinators considered the policy positive, although they made it clear that its implementation would be hard. This means the policy presents a low degree of support when it comes to implementation.

This non-compliance, however, referred to the formal policy. Even with the lack of knowledge the actors had about the policy, it was recognized as an external proposition bringing a new demand for work to be included in an environment overloaded with activities and without resources. This view was expressed in the practices adopted, which redefined the policy's goals and activities. 


\section{HUMANIZATION POLICY ACCORDING TO POLICY OPERATORS}

A research based on the management reports of the basic health units would come to the following conclusion: the National Humanization Policy was implemented in the BHUs of the city of Porto Alegre. Thus, one could say that the process was a success, since all the units would have developed their actions. This is the apparent result of the implementation process, meeting the expectations and needs of the organizations involved: $\mathrm{MH}$, SH and BHUs.

A closer look at the functioning dynamics of operating organizations, in this case the basic health units, leads to other conclusions. In fact, a Humanization Policy has been successfully implemented. However, it does not correspond to the intentions stated by the formal policy — although the formal policy has influenced the results observed.

This influence occurred through a constant exercise of resignification based, above all, on the policy's name: humanization. The term allows for several associations: being affectionate, providing good service, being polite and kind... These multiple understandings of the policy served as fundamentals to a number of activities that could be categorized as humanization. In other words, the name of the public policy worked as an input, for different processes of appropriation and interpretation, eminently local. These processes were permeated by the previous understanding of the actors, formed during training courses and/or professional experience.

Such dynamics were brought about through mediations between elements of local contexts of action vis-à-vis the normative structure of the policy. In this sense, the connection between three situations related to organizational condition were identified. First, the requirement made by the city's management body to insert the humanization activities in the management reports. Second, the lack of coordination of efforts to carry out the activities: training in policy's goals and tactics. Third, a space of implementation impregnated by the perception that resources would be insufficient. In this context, the need to make decisions has leveraged policy reformulations.

This process was done by redesigning the goals and strategies. Rather than being embodied by new tasks to be implemented, the NHP was transformed into a label applied to actions that were already part of the units' routine. As one respondent put it: "There are a lot of things that we do that are humanization and we did not know it". Moreover, the adaptation minimized the perceived lack of resources, corrected the problems of process management, accommodated different demands and needs and, mainly, made the implementation possible. The result of this process was a policy that the operators considered possible to put into practice.

For the organizations, the consequences of the reformulation were as follows: first, the Ministry of Health and the city's Secretary of Health met their demands. After all, the NHP would be widespread. Second, BHUs fulfilled their role of operators of the policies. In this way, from the internal point of view, implementing bureaucrats guaranteed their control over priorities and actions. This is because the definition of what should be done within an organization tends to be a matter of dispute between the actors. Although it is often accepted that operating agencies do not question the goals and strategies formulated hierarchically, it is possible to observe that operators decide, formulate and dispute the control over their field of action with other hierarchical levels and even with levels of government. In terms of public policy, all this generates great variability of constructions and practices.

The research showed how discretion was used and what were the consequence for the public policy, but also for the organizations involved. The discretion was activated due to the context of unawareness 
of the content to be operated, the strong perception of lack of resources and the need to respond to the demands required by the managing body. In addition, it is worth mentioning the influence of variables referring to the transmission of the policy, the characteristics of the areas of implementation and the incentives of the managing body. Discretion was definitely used in policy reformulation and the result of this process was the implementation of a Humanization Policy adjusted to the demands and needs of the operators, maintaining the control over the workspaces.

\section{FINAL CONSIDERATIONS}

The bureaucracy responsible for implementing the National Humanization Policy has built up a set of particular perceptions about the policy. The breadth and multiplicity of these perceptions increased because these bureaucrats were not familiar with the policy framework. In addition, faced with the requirement that they carry out activities of humanization, the actors adapted the activities traditionally developed in their work according to their own understanding of what the policy was. This created an interesting situation: despite the lack of training and personnel, as well as the diffuse and multiple understanding of goals and strategies, practically all the units implemented some kind of humanization policy. The use of italic to mark 'humanization policy' is to emphasize that the policies are different according to the actors' understanding. Therefore, the NHP has become an eminently local category of understanding, and this is a result of the process of interaction between the incentives of the normative structure and the characteristics of the implementation context. The formal plan of the policy offered the guiding element: the term humanization; which was afterwards adapted. This word was defined in different ways and these understandings guided the policy reformulation. The definition of humanization was mediated by organizational dynamics, by the performance of the management agency and by the limits and possibilities of organizations operating the implementation of the policy. 


\section{REFERENCES}

BASTIEN, Joelle. Goal ambiguity and informal discretion in the implementation of public policies: the case of Spanish immigration policy. International Review of Administrative Sciences, v. 75, n. 4, p. 665-685, 2009.

BRAZIL. Ministério da Saúde. HumanizaSUS: documento base para gestores e trabalhadores do SUS. Brasília: Ministério da Saúde, 2008.

BRAZIL. Ministério da Saúde. HumanizaSUS: Política Nacional de Humanização: a humanização como eixo norteador das práticas de atenção e gestão em todas as instâncias do SUS. Brasília: Ministério da Saúde, 2004a.

BRAZIL. Ministério da Saúde. HumanizaSUS: Política Nacional de Humanização: documento base para gestores e trabalhadores do SUS. Brasília: Ministério da Saúde, 2004b.

BRAZIL. Ministério da Saúde. Política Nacional de Humanização da Atenção e Gestão do SUS. O HumanizaSUS na atenção básica. Brasília: Ministério da Saúde, 2009. (Série B. Textos Básicos de Saúde)

BRODKIN, Evelyn Z. Bureaucracy redux: management reformism and the welfare state. Journal of Public Administration Research and Theory, n. 17, p. 1-17, 2007.

BRODKIN, Evelyn Z. Policy work: street-level organizations under new managerialism. Journal of Public Administration Research and Theory, n. 21, p. 253-277, 2011.

BROWNE, Angela; WILDAVSKY, Aaron. What should evaluation mean to implementation? In: PRESSMAN, Jeffrey L.; WILDAVSKY, Aaron (Ed.). Implementation. 3. ed. Berkeley: University of California, 1984. p. 232-256.

GOFEN, Anat. Mind the gap: dimensions and influence of street-level divergence. Journal of Public Administration Research and Theory, n. 24, p. 473493, 2014.

HILL, Michael; HUPE, Peter. Implementing public policy. London: Sage, 2014.

HOWLETT, Michael et al. Política pública. Seus ciclos e subsistemas. Uma abordagem integral. Rio de Janeiro: Elsevier, 2013.
HUPE, Peter. What happens on the ground: persistent issues in implementation research. Public Policy and Administration, v. 29, n. 2, p. 164-182, 2014.

HUPE, Peter et al. Studying implementation beyond deficit analysis: the top-down view reconsidered. Public Policy and Administration, v. 29, n. 2, p. 145163, 2014.

LIMA, Luciana L. A implementação da regulação dos prestadores privados no sistema municipal de saúde: os casos de Belo Horizonte/MG e Porto Alegre/RS. In: FARIA, Carlos Aurélio P. (Org.). Implementação de políticas públicas: teoria e prática. Belo Horizonte: Editora PUC Minas, 2012. p. 154-181.

LIMA, Luciana L.; D’ASCENZI, Luciano. Estrutura normativa e implementação de políticas públicas. In: MADEIRA, Lígia M. (Org.). Avaliação de políticas públicas. Porto Alegre: UFRGS/Cegov, 2014. p. 50-63.

LIMA, Luciana L.; D’ASCENZI, Luciano. Implementação de políticas públicas: perspectivas analíticas. Revista de Sociologia e Política, v. 21, n. 48, p. 101110, 2013.

LIPSKY, Michael. Street-level bureaucracy: dilemmas of the individual in public services. New York: Russel Sage Foundation, 2010.

LOTTA, Gabriela S. Desvendando o papel dos burocratas de nível de rua no processo de implementação: o caso dos agentes comunitários de saúde. In: FARIA, Carlos Aurélio P. (Org.). Implementação de políticas públicas: teoria e prática. Belo Horizonte: Editora PUC Minas, 2012b. p. 221-259.

LOTTA, Gabriela. S. O papel das burocracias do nível de rua na implementação de políticas públicas: entre o controle e a discricionariedade. In: FARIA, Carlos Aurélio P. (Org.). Implementação de políticas públicas: teoria e prática. Belo Horizonte: Editora PUC Minas, 2012a. p. 20-49.

MAJONE, Giandomenico; WILDAVSKY, Aaron. Implementation as evolution. In: PRESSMAN, Jeffrey L.; WILDAVSKY, Aaron. Implementation. California: University of California Press, 1984. p. 163-180.

MARQUES, Eduardo. As políticas públicas na ciência política. In: MARQUES, Eduardo; FARIA, Carlos Aurélio P. de (Org.). A política pública como campo multidisciplinar. São Paulo: Unesp, 2013. p. 23-46. 
MAY, Peter J. Policy design and implementation. In: PETERS, B. Guy; PIERRE, Jon (Ed.). The Sage handbook of public administration. London: Sage, 2012. p. 279-291.

MULLER, Pierre; SUREL, Yves. A análise das políticas públicas. Pelotas: Educat, 2002.

OLIVEIRA, Antonio. Burocratas da linha de frente: executores e fazedores das políticas públicas. Rev. Adm. Pública, v. 46, n. 6, p. 1551-1573, nov./dez. 2012.

PINTO, Elisabeth L.; MIDLEJ, Suylan. Programa Pró-Equidade de Gênero: uma discussão sobre relações entre homens e mulheres na Caixa Econômica Federal. Rev. Adm. Pública, v. 46, n. 6, p. 1529-1550, nov./dez. 2012.

PIRES, Roberto R. C. Estilos de implementação e resultados de políticas públicas: fiscais do trabalho e o cumprimento da lei trabalhista no Brasil. Dados, v. 52, n. 3, p.735-769, 2009.
SECCHI, Leonardo. Políticas públicas. Conceitos, esquemas de análise, casos práticos. 2. ed. São Paulo: Cengage Learning, 2015.

SOSS, Joe et al. The organization of discipline: from performance management to perversity and punishment. Journal of Public Administration Research and Theory, n. 21, p. 203-232, 2011.

TUMMERS, Lars. Explaining the willingness of public professionals to implement new policies: a policy alienation framework. International Review of Administrative Sciences, v. 77, n. 3, p. 555-581, 2011.

WILSON, James. Q. Bureaucracy: what government agencies do and why they do it. New York: Basic Books, 2000.

ZANI, Felipe Barbosa; COSTA, Frederico Lustosa da. Avaliação da implementação do Programa Nacional de Fortalecimento da Agricultura Familiar - novas perspectivas de análise. Rev. Adm. Pública, v. 48, n. 4, p. 889-912, jul./ago. 2014.

\section{Luciana Leite Lima}

$\mathrm{PhD}$ in Social Sciences from Unicamp. She is a Professor at the Post-Graduation Program in Public Policies and at the Department of Sociology of the Federal University of Rio Grande do Sul. E-mail: lucianaleitelima@ gmail.com.

\section{Luciano D'Ascenzi}

$\mathrm{PhD}$ in Social Sciences from Unicamp. He is part of the technical staff of the Department of fees and economic studies at the State Agency of Delegated Public Services Regulation in Rio Grande do Sul (Agergs). E-mail: luciano.dascenzi@gmail.com. 